\title{
The Impact of Globalization on the Insurance and Reinsurance Market of Eastern Europe
}

Goran B. Anđelić, llija Ćosić, Vladimir Đaković *

Abstract:

The analysis of the influence of globalization on the insurance and reinsurance markets of Eastern Europe confirms its significant importance in directing it towards steady increase, reflecting global trends. Special attention in this paper has been dedicated to the new thriving market in the insurance and reinsurance business as a basic indicator of market globalization with special attention to Eastern Europe. Namely, the business environment in Eastern Europe is especially dynamic and complex regarding the phase of altering its socialeconomic system. The research in this paper covers analysis of insurance and reinsurance markets of Eastern Europe with special attention on this market in the Republic of Slovenia, the Republic of Croatia and the Republic of Serbia from 2000 to 2008. The subject of this research is an overview and analysis of the reflexive relationship between the insurance and reinsurance markets of Eastern Europe and the globalization processes on both micro and macro levels. The main goal of the research is to obtain specific results about the intensity and direction of the influence of globalization processes on the course and direction of development of the insurance and reinsurance markets of Eastern Europe on the one hand, and changes in the insurance and reinsurance markets of Eastern Europe on globalization processes on the other. The basic hypothesis of this research is that there is a distinctive and strong reflexive relationship between the globalization processes and the conditions and state of the insurance and reinsurance markets of Eastern Europe. The applied methodology during the research includes analyses and synthesis methods. The research results undoubtedly confirm the significance of the relationship between globalization trends and changes in the insurance and reinsurance markets of Eastern Europe, hence providing a found and background for further research in this area.

Keywords: Globalization, Insurance, Reinsurance, New markets

JEL: G22

\section{Introduction}

The notion of globalization denotes connections, integrity and interdependence in the world covering economics, sociology, technology and the cultural, political and ecological spheres of life. Globalization has been regarded as dealing with business, a particular approach in organizing financial markets, and nowadays, even a procedure. Thus, it could be adequately understood as a unique process comprising a great number of sub-processes (such as advanced economic interdependence in the world, increased cultural influence, rapid development in the domain of information technology, new management and geopolitical challenges) that contribute the growing

DOI: $10.2478 / v 10033-010-0010-7$

* Goran B. Anđelić

University of Novi Sad,

Faculty of Technical Sciences

e-mail: gandjelic@uns.ac.rs

Ilija Ćosić

University of Novi Sad,

Faculty of Technical Sciences

e-mail: ftndean@uns.ac.rs

Vladimir Đaković

University of Novi Sad,

Faculty of Technical Sciences

e-mail: v_djakovic@uns.ac.rs 
interdependence between people and business into a unique comprehensive global system. Therefore, globalization, as an established procedure, has numerous aspects, with an emphasis on its economic aspect due to its permanent presence in the basics of globalization itself.

Globalization comprises numerous possibilities and challenges. A greater market denotes greater profit, leading to growing wealth for further investment and development as well as eliminating poverty in many countries. Badly shaped national policy, as well as institutional, infrastructure and trade barriers could seriously limit the abilities of a country to take advantage of globalization. Exact economic information provides the basis for carrying out a successful policy and information collection from different countries allows for the construction of a relative and global picture on the levels of living standards, wealth and poverty (Prekajac 2007, p. 87). In the modern world, every country and company should mightily strive for taking decisions and implementing coherent policy to maximize its efficiency and reduce globalization challenges substantially. Without further explanation of the advantages and disadvantages of globalization, the general intention is to point out the impact of globalization as a worldwide process on the insurance and reinsurance market of Eastern Europe, as well as the possibilities and challenges that insurance and reinsurance companies could face in that particular region.

\section{Theoretical Framework}

The influence of globalization as a global process on the course and effects of companies' business activities is one of the best investigated and analyzed issues in the last two decades. The dynamics of changes and conditions induced in the environment by globalization largely determine the ways in which businesses are operating and the forms of the companies' decision making. In the sense of globalization-induced influences on the course and effects of the companies' business operations, these issues are especially important for financial companies, since their activities include diversified structural activity, and they are explicitly influenced by the factors and circumstances in the environment. The special importance of research on the influence of globalization on financial companies is reflected also by the fact that the ways and effects of the business operations of these companies largely define the entire 'business climate' in the market, which on the other hand directly affects the course and effects of economic and social development in general. Insurance companies as typical representatives of financial activities are of special importance in the market, and it is vital to analyze the influence of the globalization processes on their business operations, both from scientific and practical perspectives. This issue is strongly emphasized in the case of transitional economies of Eastern European countries, since the success of reforms largely depends on the level of order within the financial sphere and its complementariness within international, global courses. These issues were investigated by several authors $S_{L}$ and Liedtke Patrick in his article 'What's Insurance to a Modern Economy?' (Liedtke 2007) investigates the connection between the modern courses and trends in the financial market through the prism of insurance activities, with special attention to the ability of insurance companies to adjust themselves to the courses and trends that globalization as a global process stimulates. The conclusions derived by the author could be reduced to the general notion that there is a strong correlative interconnection between globalization and insurance activities and that the trends of globalization are reflected in the insurance business. In his article 'The necessity of restructuring insurance companies of Serbia' Ostojic Sinisa (2004) investigates and confirms the necessity of restructuring the insurance system in the Republic of Serbia and its active inclusion in international processes. In his articles, Marovic Boris also analyzed and empirically confirmed the significance and necessity for the insurance markets of transitional economies to comply with the conditions and trends created and imposed by globalization in the international market.

Special attention has been given to the importance of the risks involved with insurance companies' operations. Namely, adequate transnational risk coverage implies the existence of an efficient global program of insurance activities. Pure risks are usually traded in insurance and reinsurance markets, although more recently the market for pure risk has expanded to include alternative risk transfer mechanisms such as captive insurance companies and securitized insurance instruments (Cummins and Weiss 2000, p. 162).

Traditional theory perceives globalization to be a demanding, lengthy, step-by-step process. The eclectic paradigm (Dunning 1979, 1988) predicts that companies decide to go international when they possess some company-specific advantages. This paradigm is actually a 
conglomerate of resource-advantage theory, international trade theory, and transaction cost-analysis theory. Later refinements to the eclectic paradigm (Dunning 1995, 2000) involve business, technological and political developments in the 1990s and try to explain globalization in terms of dynamics. We hypothesize that later stages of globalization, with their increasing positive dynamic position, are one of the most important factors for global development, both in social and business areas. Especially in the financial segment, processes of globalization significantly influence paths and trends in further development.

Bearing this in mind, the paper analyzes the condition on the local markets and the possibilities for the further advancement of the insurance and reinsurance business. Special emphasis has been given to the identification of characteristics of the insurance and reinsurance markets of Eastern Europe, as well as to the role of global insurers and reinsurers in the further growth and development of these markets.

\section{Current Trends In The Insurance And Reinsurance Global Market}

Business globalization of economic areas and the growing interdependence among people worldwide indirectly affects the insurance and reinsurance market, allowing for the creation of 'a global insurer'. Therefore, the globalization of the world economy fosters the globalization of insurance and reinsurance service. However, it is evident that these two procedures were not carried out separately, due to the fact that reinsurance service is international business in nature and nowadays slips across national borders. It is a well-known fact that risk management in insurance companies has been carried out through the application of statistics and probability theory, while deviations from average values which occur as a result of the change in economic conditions, social climate, environment effects, etc., compensate for dispersion of risk over time, space, insurance type, etc. Thus, the spatial dispersion of risk creates the need for international cooperation. Insurance companies offer international service in the form of risk insurance in foreign countries or establish daughter companies abroad while setting up a subsidiary or acquisition of foreign insurance company, which has become a more common practice nowadays. In addition, globalization of insurance and reinsurance service has been initiated by the need for following steady clients in their ambitious ventures worldwide as well as a constant search for increased profit, which can be accomplished by means of the geographic spread of the_insurance and reinsurance business (Cummins and Danzon 1997).

Globalization of the insurance and reinsurance business enables risk diversification and cost reduction, but has become feasible only after liberalization and deregulation of the once strongly protected sector. Many countries are moving away from protectionist policies and state control towards a market approach, especially in the domain of insurance and other financial services. In order to establish a stable, adequately managed and successful sector, the governments strive to deregulate insurance, privatize publicly owned companies and open markets to foreign companies. Demographic changes are the second important reason for emerging multinational insurers and reinsurers. Globalization of the insurance and reinsurance business depends on the challenges the insurers and reinsurers face on their local markets. As a consequence of the globalization of the insurance and reinsurance business, the first transnational insurance and financial companies emerged first in Europe, and include AEGON, AGF, Allianz, AXA, Generali, ING Group, Mapfre, Prudential plc, Skandia, Royal Sun Alliance, and Zurich Financial Services; and thus, subsequently in North America as well: AIG, Aetna, CIGNA, John Hancock, Manulife Financial, MetLife, New York Life, Principal Financial, Prudential, and Sun Life.

The process of the globalization of insurance and reinsurance services combined with ever-growing competition on the insurance and reinsurance market unavoidably leads to increased integration of insurance and reinsurance companies (Plunkett 2007). The process of consolidation, which means merging and joining insurance and reinsurance companies, has been led by the desire to increase market strength, decrease costs and develop economies of scale. The growing consolidation of insurance and reinsurance companies is emerging as the consequence of the fact that only a few of the large insurance groups will have available capital sufficient to achieve global domination since new regulation, including the Sarbanes-Oxley Act in the US and Solvency II in Europe, is going to allow more competitive positions for large insurance companies in comparison with smaller ones; but only a few of them will be able to provide adequate managerial skills to achieve success in all areas of insurance in a more open and competitive environment (in the domain of life insurance, globalization has largely contributed to the 
intensification of competition) (Santomero and Cummins 1999).

The consolidation of insurance companies of non-life insurance unfolded slower than insurance companies of life insurance, although the character of non-life insurance in its broadest sense is more global than that of life insurance, especially with regard to determination of premiums in liability insurance as well as capability of global risk distribution. There are a small number of large insurance companies providing a wide range of insurance services to their corporate clients, including services of global insurance of property and liability. The leading global insurance companies in 2008 are represented in Table 1.

\begin{tabular}{|c|c|c|c|}
\hline Rank & Company & $\begin{array}{l}\text { Revenues (2) } \\
\text { (mil. USD) }\end{array}$ & Country \\
\hline 1 & $\begin{array}{l}\text { Japan Post } \\
\text { Holdings }\end{array}$ & 198,700 & Japan \\
\hline 2 & Allianz & 142,395 & Germany \\
\hline 3 & $\begin{array}{l}\text { Berkshire } \\
\text { Hathaway }\end{array}$ & 107,786 & USA \\
\hline 4 & $\begin{array}{l}\text { Assicurazioni } \\
\text { Generali }\end{array}$ & 103,103 & Italy \\
\hline 5 & AXA & 80,257 & USA \\
\hline 6 & $\begin{array}{l}\text { Munich Re } \\
\text { Group }\end{array}$ & 67,515 & Germany \\
\hline 7 & $\begin{array}{l}\text { Nippon Life } \\
\text { Insurance }\end{array}$ & 66,621 & Japan \\
\hline 8 & $\begin{array}{l}\text { State Farm } \\
\text { Insurance } \\
\text { Cos. }\end{array}$ & 61,343 & USA \\
\hline 9 & MetLife & 55,085 & USA \\
\hline 10 & $\begin{array}{l}\text { China Life } \\
\text { Insurance }\end{array}$ & 54,534 & China \\
\hline
\end{tabular}

(1) Based on an analysis of companies in the Global Fortune 500. Includes stock and mutual companies.

(2) Revenues include premium and annuity income, investment income and capital gains or losses, but exclude deposits; includes consolidated subsidiaries, excludes excise taxes.

Source: Insurance Information Institute, http://www.iii.org/international/rankings/

Table 1: Leading insurance companies in the world in 2008 (1) by revenue (in millions of dollars)

Business concentration is the most apparent in the area of reinsurance, since the ten leading reinsurers signed $60 \%$ of the world's reinsurance premiums in comparison with $40 \%$ ten years ago. The process of globalization of reinsurance business has been accompanying ambitions of achieving economies of scale and risk diversification, and thus results in a strong consolidation of reinsurers, realized through merging and joining reinsurance companies, and which directly affects the increasing dependence of insurance companies in the increasingly concentrated global sector of reinsurance.

Below is a list of the leading reinsurance companies in the world from 2008 (Table 2). Due to the everchanging financial industry, it is difficult to say who the largest reinsurers are currently. For example, in early February 2009, shares in the world's second largest reinsurer, Swiss Re, dropped 28\% (the most in 19 years) after appealing to Berkshire Hathaway for more than \$2.5 billion to help restore capital as a result of record losses since the financial crisis began.

\begin{tabular}{|c|c|c|c|}
\hline Rank & Company & $\begin{array}{c}\text { Net } \\
\text { reinsurance } \\
\text { premiums } \\
\text { written } \\
\text { (mil. USD) }\end{array}$ & Country \\
\hline 1 & $\begin{array}{l}\text { Munich Re } \\
\text { Group }\end{array}$ & $30,379.7$ & Germany \\
\hline 2 & $\begin{array}{l}\text { Swiss Re } \\
\text { Group }\end{array}$ & $23,724.3$ & $\begin{array}{l}\text { Switzerlan } \\
\text { d }\end{array}$ \\
\hline 3 & $\begin{array}{l}\text { Berkshire } \\
\text { Hathaway/Ge } \\
\text { n Re Group (1) }\end{array}$ & $11,441.0$ & USA \\
\hline 4 & $\begin{array}{l}\text { Hanover Re } \\
\text { Group }\end{array}$ & $10,653.2$ & Germany \\
\hline 5 & $\begin{array}{l}\text { Lloyd's of } \\
\text { London }\end{array}$ & $8,588.2$ & U.K. \\
\hline 6 & SCOR & $8,551.4$ & France \\
\hline 7 & $\begin{array}{l}\text { Transatlantic } \\
\text { Holdings Inc. }\end{array}$ & $4,108.1$ & USA \\
\hline 8 & PartnerRe Ltd. & $3,989.4$ & Bermuda \\
\hline 9 & $\begin{array}{l}\text { ACE Tempest } \\
\text { Reinsurance } \\
\text { Ltd. (2) }\end{array}$ & $3,961.0$ & Bermuda \\
\hline 10 & $\begin{array}{l}\text { Everest Re } \\
\text { Group Ltd. }\end{array}$ & $3,505.2$ & Bermuda \\
\hline
\end{tabular}

(1) Combined figures of Berkshire Hathaway Reinsurance Group and General Re Group.

(2) Includes all reinsurance business performed by subsidiaries of ACE Ltd.

Source: Insurance Information Institute, http://www.iii.org/international/rankings/

Table 2: Leading reinsurance companies in the world in 2008 by Net reinsurance premiums written (in millions of dollars) 
In order to be competitive in the era of globalization, insurance and reinsurance companies should steadily improve their efficiency and productivity, and at the same time their ability to provide insurance and reinsurance services in an efficient way has become a valuable source of competitive advantage (Ghosh and Ariff 2004). Thus globalization leads to launching and developing new insurance products that are global in character but at the same time carefully matched to individually insured clients with the aim of satisfying their demands.

\section{1 'New trends' in selected Eastern European countries}

Since 1989 the markets of selected Eastern European countries, or countries commonly understood as in transition (i.e. selected emerging markets such as the Czech Republic, Poland, Slovakia, Hungary, Slovenia, Croatia, $\mathrm{BH}$, Montenegro and Serbia) have been attracting more and more global insurance and reinsurance companies, which is a consequence of the_liberalization, de-monopolization and privatization of national insurance and reinsurance markets, economic and political reforms, creation of conditions for the free flow of capital and workforce, and the achievement of a high average rate of economic growth in these countries as well as the integration of a large number of Eastern European countries into the European Union in 2004 and 2007. The international financial integration of transitional countries results from-global and regional integration (Mirdala 2008, p. 221). As the result of these changes and the fact that Eastern European countries provide global insurance companies with a potential for long--term business growth and advancement, during the 90 's the insurance business started emerging in these countries, where in the former environment of socialist public ownership and management, it was guaranteed or considered unnecessary. This was primarily due to direct foreign investments by large insurance companies such as Allianz, AXA, Prudential, and Winterthur (Hamilton, Pichler-Milanović and Andrews 2005).

Before the significant admission of foreign insurance companies during the 90 's, the insurance and reinsurance markets of selected Eastern European countries were dominated by motor vehicle insurance and property insurance. As global insurance and reinsurance companies entered the markets, the publicly owned insurance companies lost their monopoly and the structure of insurance business changed in favor of commercial and life insurance. Global insurers and reinsurers on the markets of selected Eastern European countries have an opportunity to sell products that have saturated the markets in their parent countries. In addition, in these new markets they have an initial competitive advantage against domestic companies, which is due to their long standing business experience, financial strength and knowledge. The most harmful effects of globalization on insurance and reinsurance markets for global insurers and reinsurers are the examples of very expensive breaks into new markets, both regarding acquisition of existing insurance and reinsurance companies as well as developing selling channel networks. Apart from the above cited advantages of globalization for global insurance companies, it also offers certain advantages for the selected Eastern European countries that allow massive expansion of large insurance and reinsurance companies. Meanwhile, they extend new knowledge, fresh capital, sophisticated insurance products, marketing standards that significantly increase the level of awareness of the customers, adequate capacities for covering huge risks, and expertise for accepting new risk cover. Enhancing the level of confidence in the institution of insurance, they facilitate the level of customer education, which on its side increases demand, especially for products of life insurance, which both the global and local insurance and reinsurance companies benefit from.

A few of the leading insurers, typically former monopolies with publicly owned capital, claim the prevailing share on insurance and reinsurance markets of selected Eastern European countries. This is implied by examples from the two largest markets in the region. In Poland, the prevailing share is owned by the two leading insurers, PZU and Warta, and in the Czech Republic Ceska pojistovna and Kooperativa. However, liberalization, i.e. removing the barriers in order to allow foreign insurance and reinsurance companies to enter the markets, harmonized national legislation with EU regulations, a relatively sophisticated system of supervision, and the admission of these countries into full EU membership, contributed to the appearance of insurance companies with foreign capital. The reinsurance market in these countries is characterized by a small number of reinsurers, including the leading reinsurers in the world. Munich Re, Swiss Re, ERC Group, Partner Re, GeneralCologne Re, Hannover Re, Converium, SCOR, Lloyd's, Everest Re and PXRE are among those present in the region.

Stimulation for globalizing insurance and reinsurance markets in selected Eastern European 
countries will be provided by the need of global insurers and reinsurers to follow their clients outside national borders, as well as the need for constant search after risk diversification and the development of economies of scale. The partial privatization of the social security system, such as retirement and health insurance, creates new business opportunities for experienced and financially strong global insurers in the markets of these countries. Also, the process of the liberalization of insurance and reinsurance markets of selected Eastern European countries, followed by the process of transformation and privatization of former publicly owned insurance companies, as well as the process of consolidation of insurance and reinsurance companies in the markets of these countries, create additional resources for opening these markets for global insurance companies in the coming period as well.

\subsection{Selected countries of the former Yugoslavia - Slovenia, Croatia, BH, Montenegro and Serbia}

Although the same trends characterizing the entire region of Eastern Europe are present in business ventures of insurance and reinsurance companies in the region of the former SFRY, there is a strong need to depict the characteristics of insurance and reinsurance markets in the republics of the former state in more detail, with special attention to the insurance and reinsurance market of the Republic of Serbia.

Regarding the countries of the former Yugoslavia, Slovenia has been the most developed country both generally and in the domain of the insurance and reinsurance market; it is the one country from the former Yugoslavia which currently has full EU membership. When speaking about the conditions of setting up insurance companies, insurers providing services of life and non-life insurance in Slovenia need to obtain initial capital in the amount of $€ 4.4$ million, non-life insurers $€$ 2.4 million, life insurers $€ 2$ million, and reinsurers $€ 2.4$ million (The Insurance Act, No. 109/06, 114/06 and 9/07). On this market there were 16 operating companies, of whom two were reinsurance companies, in 2007. This market is dominated by insurance companies with a majority of domestic capital (it accounted for over $91 \%$ of total premium payments), especially in the domain of non-life insurance, but in life insurance as well, which distinguishes Slovenia from the rest of the countries of the former Yugoslavia. The Slovenian insurance market is markedly concentrated since the leading insurance company, Triglav, has a market share of over $38 \%$, and the first five insurance companies over $86 \%$, according to the amount of attributed premium (SIA 2008). The collected gross insurance premium structure in Slovenia is shown in Figure 1 and the portfolio structure of insurance is shown in Figure 2.

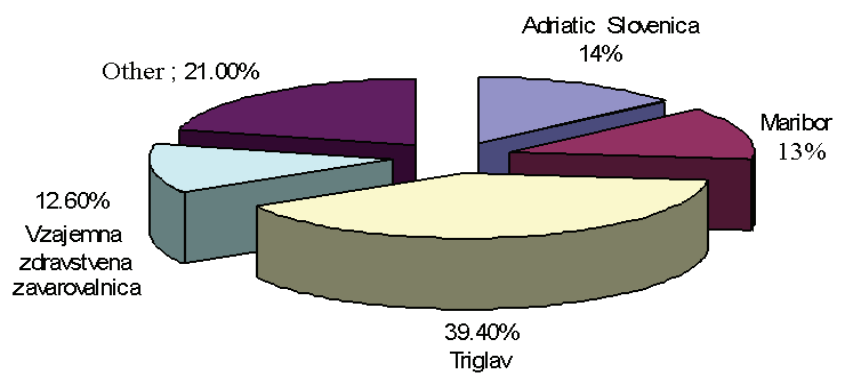

Source: SIA, Statistical Insurance Bulletin, 2008

Figure 1: Collected gross insurance premiums structure in Slovenia in 2007

In the field of property insurance in 2007, Triglav insurance holds $52.6 \%$ of the market share, Zavarovalnica Maribor holds $18.6 \%$ and Adriatic Slovenica zavarovalna druzba holds $15.8 \%$. Similarly, in the field of life insurance, Triglav holds 43.9\%; Zavarovalnica Maribor holds $12.1 \%$ and $K D$ Zivljenje $11.2 \%$. However, in the field of voluntary health insurance, $61.7 \%$ of the market is held by Vzajemna zdravstvena zavarovalnica, while Adriatic Slovenica has $24.3 \%$ and Triglav zdravstvena zavarovalnica $14 \%$. The Slovenian insurance and reinsurance market in 2007 was characterized by the participation of 305 insurance companies from the EU. Of those, 80 insurance companies (26.2\%) were from Great Britain, 31 from Ireland, 31 from Austria, 21 from Italy, 20 from Germany, 19 from Luxemburg and 12 from France (SIA 2008).

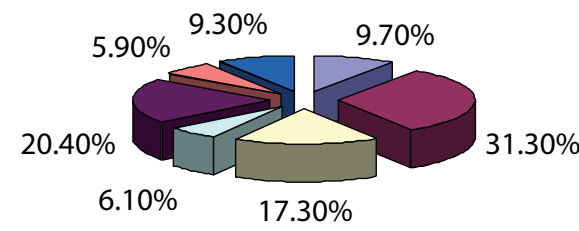

Casco car $\square$ Life insurance

Motor vehicle liability insurance $\quad$ Health insurance

Other insurances $\square$ Casualty insurance

Property insurance

Source: SIA, Statistical Insurance Bulletin, 2008

Figure 2: The portfolio structure of the insurance business in Slovenia in 2007 
According to the level of development of insurance markets in the countries of the former Yugoslavia, Croatia is in second place after Slovenia. Croatia has the most rigorous requirements for setting up insurance companies in the entire region. Typically, setting up insurance companies dealing with non-life and life insurance require an initial capital of $€ 145.5$ million, for non-life insurers $€ 25.3$ million, for life insurers $€ 12.3$ million, and for reinsurers $€ 18.9$ million (The Insurance Act, No. 151/05). In 2007 there were 26 operating companies; two of them were reinsurers, six life insurers, eight non-life insurers, ten were insurance companies dealing both with life and non-life insurance and one a pool for insurance and reinsurance of nuclear risks on the Croatian insurance and reinsurance market. The founders of the Croatian pool for insurance and reinsurance of nuclear risks are Croatia osiguranje, Croatia Lloyd, Helios osiguranje, Triglav osiguranje and Allianz Zagreb (Croatian Financial Services Supervisory Agency 2008). The collected gross insurance premium structure in Croatia is shown in Figure 3.

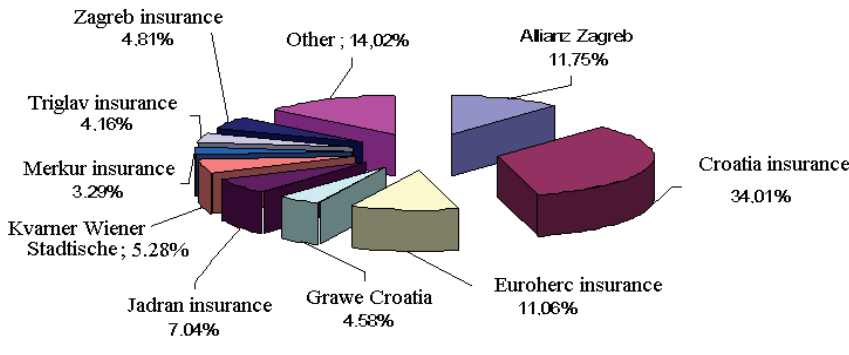

Source: Croatian Financial Services Supervisory Agency, Annual report, 2008, www.hanfa.hr

Figure 3: Collected gross insurance premium structure in Croatia in 2007

Most are under a foreign ownership. Companies under foreign ownership have predominant positions on the life insurance market, whereas companies established on domestic capital prevail in the domain of non-life insurance. The collected gross insurance premiums in Croatia in 2007 were 1,689 million USD. The insurance market in Croatia, as in Slovenia, is highly concentrated, with the top five insurers holding $63.86 \%$ of the market share; in 2007 the leading insurance company, Croatia osiguranje, contributed $34.01 \%$ to the total of insurance premiums. The portfolio structure of Croatian insurers is shown in Figure 4.

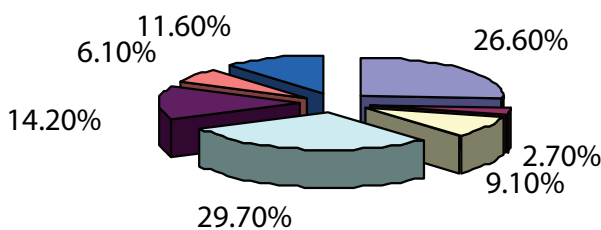

Life insurance $\quad \square$ Health insurance

Other insurances $\quad \square \begin{aligned} & \text { Motor vehicle liability } \\ & \text { insurance }\end{aligned}$

Property insurance $\square$ Casualty insurance

Road vehicles - comprehensive insurance

Source: Croatian Financial Services Supervisory Agency, Annual report, 2008, www.hanfa.hr

Figure 4: Portfolio structure of insurance business in Croatia in 2007

With regard to the requirements of establishing an insurance company in $\mathrm{BH}$, i.e. the conditions necessary for setting up a company, they are the same as in Slovenia, which means that insurers providing services of life and non-life insurance need to have initial capital of $€ 4.4$ million, non-life insurers $€ 2.4$ million, life insurers $€ 2$ million, and reinsurers $€ 2.4$ million (Law on Insurance Companies in Private Insurance, No. 24/05 and Law on Insurance Companies, No. 17/05, 01/06, and 64/06). BH has a very complex legal and institutional framework for such a small insurance and reinsurance market. The insurance and reinsurance business is organized and regulated on the entity level, with the Insurance Agency of B\&H providing oversight at the state level. The State Agency harmonizes the entities' legislation and the supervisory work of the entity's agencies, organizes statistics at the state level and represents the country in international relations. In 2007, on the insurance market of $\mathrm{BH}$, including both entities, the Federation of $\mathrm{BH}$ and the Republika Srpska, there were 26 operating companies (Federation of BH - 16 and the Republika Srpska - 10) of which one was a reinsurance company, one was a life insurance company, 15 were non-life insurance companies and nine were insurance companies dealing with both life and non-life insurance (Insurance Agency of $B \& H$ 2008). Insurance companies in BH are still under domestic majority ownership, but there are ten companies under foreign ownership. The collected gross insurance premium structure in $\mathrm{BH}$ is shown in Figure 5 . 


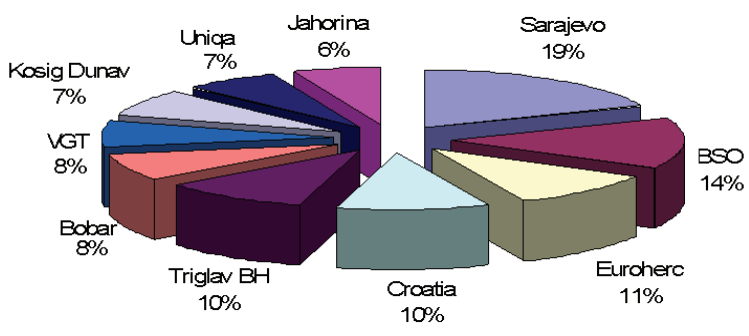

Source: Insurance Agency of B\&H, Statistics of Insurance Market in Bosnia and Herzegovina, 2008

Figure 5: Collected gross insurance premium structure in BH in 2007

The $\mathrm{BH}$ market is highly concentrated, with the top five insurers holding $45.98 \%$ of the market share; the predominant contribution to the market share is that of the Sarajevo osiguranje company. The leading insurance company in the Republika Srpska is Bobar osiguranje. The portfolio structure of the insurance business in $\mathrm{BH}$ is shown in Figure 6.

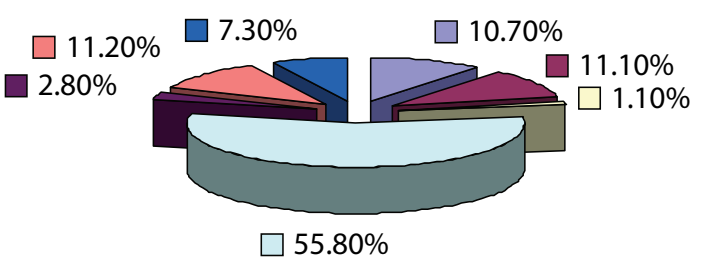

Road vehicles - comprehensive insurance

Life insurance

Other insurances

Motor vehicle liability insurance

Health insurance

Property insurance

Casualty insurance

Source: Insurance Agency of B\&H, Statistics of Insurance Market in Bosnia and Herzegovina, 2008

Figure 6: The portfolio structure of the insurance business in BH in 2007

In Montenegro, insurers providing services of life and non-life insurance need to have initial capital in the amount of $€ 32$ million, for non-life insurers it is $€ 27.85$ million, for life insurers $€ 2.22$ million, and for reinsurers $€$ 1.95 million (Law on Insurance, No 78/06). In 2006, insurance market premiums rose by $18 \%$ and accounted for $2.1 \%$ of GDP. Although there are six insurance companies in the country, Lovcen osiguranje maintained a dominant market share (70\%). The sector is dominated by car insurance $(51 \%)$, while the life segment, which is less developed, accounts for less than $5 \%$ of billed premiums.
An insurance law, establishing an independent supervisory agency, was adopted at the end of 2006. The government passed the law on receivership and liquidation of insurance companies in June 2007, thus completing the legal framework of the insurance and reinsurance sector. The proposed legislation defines the terms of and procedures for receivership, voluntary and judicial liquidation of insurance companies and the rights and liabilities of parties to these proceedings. In addition, three insurance companies have reestablished a mutual guarantee fund (absent since the dissolution of the state union with Serbia). In 2007, the sector expanded further with the entry of two new firms, including the first life insurance company, but the sector remained highly concentrated since the three leading insurers in 2007 held around $98 \%$ of the market share, to which the leading Lovcen osiguranje contributed with around $66 \%$ (SY MNE 2008). The portfolio structure of the insurance business in Montenegro is shown in Figure 7.

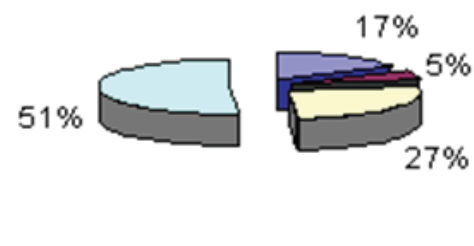

$\square$ Casualty insurance

Life insurance

$\square$ Property insurance

Motor vehicle liability insurance

Source: MONSTAT, Statistical Yearbook (SY MNE), 2008

Figure 7: The portfolio structure of the insurance business in Montenegro in 2007

The greatest change to the insurance market of Serbia happened after the passing of the new Insurance Law in 2004 (Insurance Law, No. 55/04 and 70/04). It defines new rules of behavior, so the requirement of initial capital was raised (for example, $€ 4$ million for dealing with life insurance, including retirement insurance, $€ 4.5$ million for dealing with any non-life insurance and $€ 4.5$ million for dealing with reinsurance), in comparison with previous regulations. The National Bank of Serbia was appointed as the supervising body of the entire financial system, including insurance companies and pension funds. Serbia joined the international exchange by allowing insurance companies to invest their assets into foreign financial markets. The general interest of foreign insurance companies to enter 
the Serbian insurance market, both through greenfield investments and acquisition of existing insurance companies has been growing steadily as a result of repeated attempts to harmonize the domestic market with European legislation. This interest is specially expressed in the domain of life insurance, which was extremely undeveloped in the period before 2004; its development has been enabled also with the new Insurance Law that considers the possibility of expressing insurance coverage in Euros.

The number of insurance companies rose from 17 in 2006 to 20 in 2007. Of this number, 17 companies engaged in insurance activities only, two in reinsurance, and DDOR Novi Sad, a stock company dealing with both insurance and reinsurance. Of the companies engaged in insurance activities, four engaged in life insurance, eight in non-life insurance, and six in both life and non-life insurance operations. From the existing 20 insurance companies (Credit Agricole Life is the first insurance company under foreign ownership which represents a greenfield investment), 13 are under private foreign ownership and seven companies under majority domestic ownership. Only one insurance company is in state-social ownership, Dunav, which dominates the insurance market of Serbia, together with the privatized DDOR Novi Sad. The majority owner of DDOR Novi Sad is the Italian insurance company Fondiaria-SAI. The contribution of insurers DDOR Novi Sad and Dunav as two leading insurance companies on the market is $67.8 \%$, Delta Generali and Weiner Stadtische 18.3\%, while the other 12 insurers have 13.8\% (Association of Serbian Insurers 2009). The collected gross insurance premium structure in Serbia is shown in Figure 8.

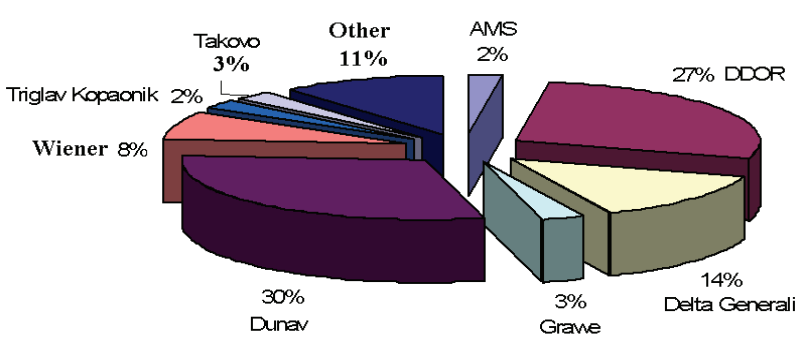

Source: NBS, Insurance Sector in the Republic of Serbia - annual report, 2008

Figure 8: Collected gross insurance premium structure in Serbia in 2007

Recently three foreign companies took over three domestic insurance companies and became their majority owners: Triglav from Slovenia took over the
Kopaonik insurance company, Sava from Slovenia took over the Polis insurance company, and Uniqua from Austria took over the Zepter insurance company. During the first half of 2007, the National Bank of Serbia issued two more greenfield licenses, one for non-life insurance Uniqua non-life insurance and one for Merkur insurance, an insurance company dealing solely with life insurance. Beside insurance companies, the sales network comprises 44 legal subjects, 87 entrepreneurs, one travel agency, three banks and 3,982 individuals holding the license of insurance mediator. The portfolio structure of the insurance business in Serbia is shown in Figure 9. Also, non-life and life insurance premiums in the Serbian insurance market are shown in Figure 10.

0.38

9.58

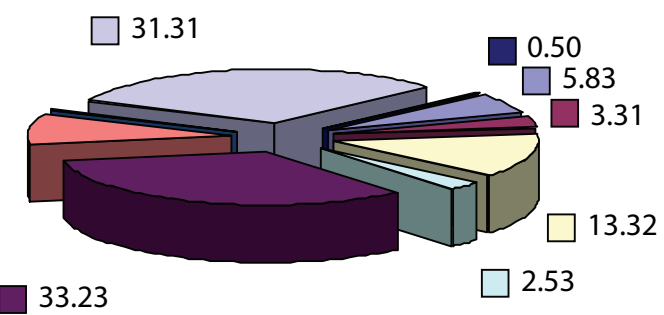

$\square$ Insurance against the consequences of accident

$\square$ Voluntary health insurance

$\square$ Insurance of motor and railway vehicles

$\square$ Transport insurance (cargo+casco)

Insurance of motor vehicles, aircrafts and vessels aqainst reliability

$\square$ Other types of life insurances

$\square$ Voluntary retirement insurance

$\square$ Other property insurances

- Credit insurance

Source: NBS, Insurance Sector in the Republic of Serbia - annual report, 2008

Figure 9: Portfolio structure of the insurance business in Serbia in 2007

The developmental potential of the insurance and reinsurance market in Serbia is high. Namely, estimations predict that $50 \%$ of the population of 7.5 million could obtain life insurance, but only 350,000 are insured presently, of which 100,000 are insured through pension funds (Association of Serbian Insurers 2009). 

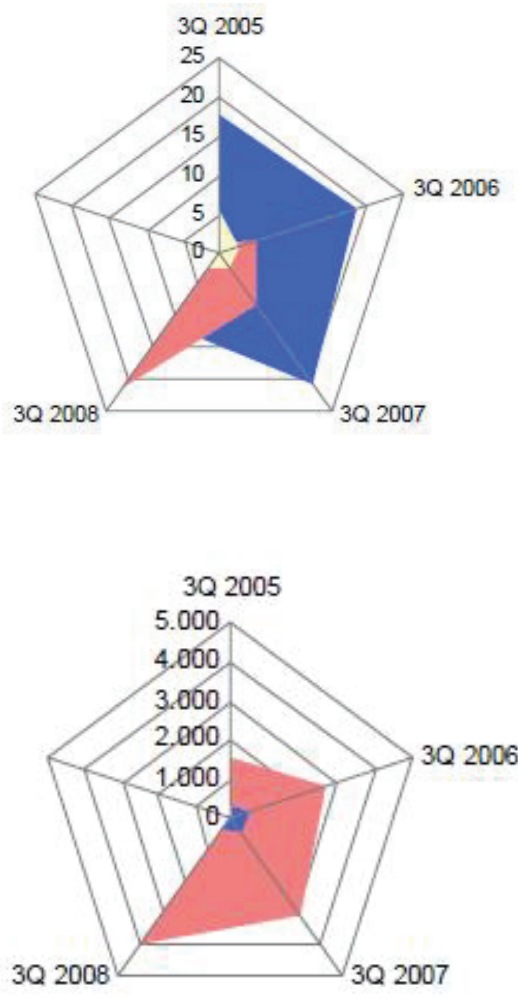

- Majority state and social ownership

- Majority foreign ownership

Majority domestic private ownership

Source: NBS, Insurance Sector in the Republic of Serbia - annual report, 2008

Figure 10: Premiums of non-life (RSD bln) and life (RSD mln) insurances in $3 Q 2005,2006,2007$ and 2008

The reasons for undeveloped life insurance in Serbia are the low level of income per capita, i.e. low purchasing power, strong suspicion of insurance as an institution, lack of knowledge about product characteristics and the long-term instability of the national currency. All the abovementioned reasons for the low presence of life insurance in Serbia have been eliminated by passing the Insurance Law in 2004.

\subsection{Globalization as ideology versus the theory of national markets}

The main goal of this paper is to determine the strength of interaction between globalization as a process on the one hand and the circumstances and trends in insurance and reinsurance markets of Eastern Europe on the other, and to describe the main factors that cause changes between these processes. With that purpose, the authors conducted research on three countries of the former Yugoslavia (Slovenia, Croatia and Serbia), covering the period from 2000 to 2008. The applied methodology during the research includes analyses and synthesis methods.

The processes of globalization have inevitably led to changes in national insurance and reinsurance markets (especially in the transitional economies of Eastern Europe, which is in the phase of altering its socialeconomical system), but changes in these national markets also indicate certain modifications and new trends in the process of globalization. The subject of this paper and investigation is to analyze and understand the pace, direction and intensity of these changes, with a special focus on the significant interdependences and similarities arising in the national insurance and reinsurance markets of Eastern Europe. The investigation in this paper focuses on selected countries of Eastern Europe (i.e. selected emerging markets such as the Czech Republic, Poland, Slovakia, Hungary, Slovenia, Croatia, BH, Montenegro and Serbia) especially regarding their undoubtedly high potential for adapting to challenging globalization processes. Transitional economies undergo economic liberalization, macroeconomic stabilization where immediate high inflation is brought under control, and restructuring and privatization in order to create a financial sector and move from public to private ownership of resources. These changes affect insurance and reinsurance markets and create a necessity for fundamentally different governmental institutions and the promotion of private-owned enterprises, markets and independent financial institutions.

Therefore, the investigation is conducted with the goal of obtaining specific data about the presence and intensity of the correlation between the insurance and reinsurance market of Eastern Europe and globalization processes, in order to better understand the anticipated changes, so that these markets can finely adjust to the challenges of globalization. The investigation includes the national insurance and reinsurance markets of the Republic of Slovenia, the Republic of Croatia and the Republic of Serbia, since these are social and economic systems in different phases of transition (the Republic of Slovenia is a full member of the European Union, the Republic of Croatia is on its way towards accession to the Union, while the Republic of Serbia is in the process of becoming an EU candidate state). Common to all these regions is the driving ambition to become a full member of the European Union as soon as possible and therefore 
to harmonize their national legislation with that of the European Union, meaning that their markets will become a part of the international world market.

Thus, the investigation includes a study of several basic parameters of national insurance and reinsurance markets and aims to answer the following questions:

1) How has the national legislation adjusted to the changes and requirements of the global environment?

2) What were the challenges that national insurance and reinsurance markets faced in the process of adjusting to global trends?

3) Are there any similarities and differences between these markets, and what is their importance in terms of their influence on the processes and trends of globalization?

The investigation covers the period from 2000 to 2008, since it was characterized by intense changes and influence on both the global processes on circumstances and conditions in these markets, and the attempts of national legislation to respond to these challenges as quickly as possible. The investigation is divided into two phases. The first phase comprises comparative analysis and testing of the reflexive relationship and interdependence of selected Eastern European countries (Slovenia, Croatia and Serbia) and EU 15 countries in 2007 based on relevant economic facts and figures. The second phase of the investigation comprises detailed analysis and determination of changes in the intensity and adjustment of the examined insurance and reinsurance markets to the requirements of the global environment.

\section{The results obtained from these investigations are the following:}

The insurance and reinsurance markets of Slovenia, Croatia and Serbia are mutually correlated, although their markets are at different stages of development. Namely, their potential for further growth and development based on relevant economic facts and figures is undisputed, especially in contrast to EU 15 countries. Slovenia has the most developed insurance and reinsurance market of the selected countries, although there is the possibility for its significant advancement regarding EU 15 countries' insurance and reinsurance market data. Hence, in 2007 collected premiums per capita of citizens (mil. USD), collected gross premiums (mil. USD) and collected gross premiums as \% of GDP were 1,294; 2,592 and 5.7, respectively, in Slovenia and 3,306; 1,539,968 and 9.16, repsectively, in EU 15 countries (Table 3).

\begin{tabular}{|c|r|r|r|r|}
\hline & Slovenia & \multicolumn{1}{|c|}{ Croatia } & Serbia & EU 15 \\
\hline $\begin{array}{c}\text { GDP per capita } \\
\text { of citizens } \\
\text { (USD) }\end{array}$ & 23,000 & 11,086 & 5,676 & - \\
\hline $\begin{array}{c}\text { Population } \\
\text { (in 000) }\end{array}$ & 2,000 & 4,600 & 7,500 & - \\
\hline $\begin{array}{c}\text { Collected } \\
\text { premiums per } \\
\text { capita of } \\
\text { citizens } \\
\text { (mil. USD) }\end{array}$ & 1,294 & 370 & 103 & 3,306 \\
\hline $\begin{array}{c}\text { Collected gross } \\
\text { premiums } \\
\text { (mil. USD) }\end{array}$ & 2,592 & 1,689 & 766 & $1,539,968$ \\
\hline $\begin{array}{c}\text { Collected gross } \\
\text { premiums } \\
\text { in \% GDP }\end{array}$ & 5.7 & 3.3 & 1.8 & 9.16 \\
\hline $\begin{array}{c}\text { Number of } \\
\text { insurance } \\
\text { societes }\end{array}$ & 16 & $27.31: 72.69$ & $12: 88$ & $64: 36$ \\
\hline $\begin{array}{c}\text { Life/Non-life } \\
\text { insurance } \\
\text { (\%) }\end{array}$ & $28.5: 51$ & 20 & 14.38 & - \\
\hline $\begin{array}{c}\text { Regional market } \\
\text { share } \\
\text { (\%) }\end{array}$ & 48.65 & 20 & & \\
\hline
\end{tabular}

Source: EUROSTAT, Statistics Databases, http://epp.eurostat.ec.europa.eu Table 3: Comparative analysis of the countries in region versus EU 15 in 2007

The differences between the insurance and reinsurance markets of Croatia and Serbia are not significant, but they are considerable in comparison to the insurance and reinsurance markets in Slovenia and EU 15 countries. Namely, in 2007 collected premiums per capita of citizens (mil. USD), collected gross premiums (mil. USD) and collected gross premiums in \% GDP were 370; 1,689 and 3.3, respectively, in Croatia and 103; 766 and 1.8, respectively, in Serbia (Table 3).

The abovementioned results correspond to different phases of transition and the EU integration processes of Slovenia (insurance and reinsurance market harmonization), Croatia (EU accession process) and Serbia (submission of candidacy for full EU membership). It is necessary to investigate further and in detail the 
characteristics and interdependence of the selected insurance and reinsurance markets and the influence of global processes on the circumstances and conditions in these markets. These results are as follows:

1) Since the dynamic changes in insurance and reinsurance markets, the national legislations of the Republic of Slovenia, the Republic of Croatia, and the Republic of Serbia have been adjusted to new conditions. Bearing in mind the fact that before 1990 insurance and reinsurance markets in these countries operated within one country, the system and legislation bases were the same. On a global scale, however, the later period was characterized by accelerated market development, and each country has adjusted to the changes independently. The analysis of legislation in the area of insurance and reinsurance markets indicates the dynamics and complexity of changes in this area.

\section{a) The Republic of Slovenia}

Development of prudential supervision in Slovenian insurance - The beginning was the Insurance Act 1994. The Insurance Act presented for the first time the principles of guarantee funds, solvency margins, prudent asset management and prudent reserving.

A supervisory authority was also established, which was essential for the further development of the insurance and reinsurance market. The same rules for insurance and reinsurance companies were established. The legal framework is not completely in line with EC directives with regard to the items of solvency margin. Also, there is no obligation to organize internal audits within insurance undertakings.

The improvements that were implemented in the Insurance Act 2000 were especially important because they created a sustainable climate for globally influenced insurance and the reinsurance market. Those improvements include the following:

- a guarantee fund was raised (amounts to almost double the guarantee fund prescribed by the first, second and third EC directives);

- not only following the rules of EC directives with regard to solvency margin, but prescribing even stricter ones, etc;

- the obligation to organize internal audits within insurance undertakings;

- additional control over insurance undertakings constituting an insurance group, etc.

The stricter rules of the Insurance Act 2000 regarding the solvency margin in accordance with EC directives were necessary to implement because of the globalization driven liberalization process in insurance and reinsurance markets.

The available solvency margin of each insurance company (and pension company) is reduced also by its investments in shares and subordinated debt instruments issued by other insurance undertakings or other financial organizations:

- in which the insurance undertaking holds a stake of over $10 \%$;

- other than those referred to in the item above, to a volume exceeding $10 \%$ of the insurance undertaking's capital.

The current Slovenia insurance and reinsurance market is regulated by:

- The Insurance Act - official consolidated text (Official Gazette of the Republic of Slovenia, No. 109/06, 114/06 and 9/07),

\begin{tabular}{|c|c|c|}
\hline SLOVENIAN INSURANCE LEGISLATION & IMPROVEMENTS & $\begin{array}{c}\text { WEAKNESS } \\
\text { (NOT IN LINE WITH EC DIRECTIVE) }\end{array}$ \\
\hline $\begin{array}{c}\text { Solvency requirement of a reinsurance } \\
\text { company }\end{array}$ & $\begin{array}{c}\text { No need for establishing a } \\
\text { national solvency }\end{array}$ & $\begin{array}{c}\text { Not including-non - Member State } \\
\text { insurance undertakings }\end{array}$ \\
\hline Definition of an insurance group & - & $\begin{array}{c}\text { The definition of a controlling undertaking } \\
\text { does not include participating in } \\
\text { undertakings }\end{array}$ \\
\hline
\end{tabular}

Source: ISA, Annual report 2008

Table 4: Comparison - Slovenian Insurance Legislation: EC Insurance Group Directive 
- The Compulsory Motor Third-party Act - official consolidated text (Official Gazette of the Republic of Slovenia, No. 110/06),

- The Health Care and Health Insurance Act - official consolidated text (Official Gazette of the Republic of Slovenia, No. 72/06),

- The Insurance Contracts Tax Act (Official Gazette of the Republic of Slovenia, No. 57/99 and 73/05),

- The Pension and Disability Insurance Act - official consolidated text (Official Gazette of the Republic of Slovenia, No. 109/06, 112/06 and 114/06)

The legal framework is especially important concerning insurance groups as a prevailing organizational form of insurance and reinsurance companies' integration (Table 4).

The Decision on Supervision of an Insurance Group (January 2001) prescribes the method of calculating adjusted capital requirements (method 2, i.e. the requirement deduction method, in accordance with Annex I of the Directive 98/78/EC on the supplementary supervision of insurance undertakings in an insurance group) and the detailed content and deadlines for reporting.

\section{b) The Republic of Croatia}

Solutions visible in Croatian insurance legislation are both positive and negative. In the Law on Insurance (passed in 2005) the clauses on the capital of insurance companies, the ways indispensable (guarantee) funds are calculated, and the limitations on investments all should be changed, since the existing solutions are very restrictive and prevent investments into more profitable products. The following changes should also be introduced: regulations on bankruptcy which are consistent with the regulations of the Bankruptcy Law (passed in 1997, complemented in 2006) and easier to realize in practice; regulations on mediators in insurance and the requirements one must meet to practice the insurance business, with special focus on the ways of obtaining licenses requiring higher education; regulations on obtaining approval for the members of the managing board of insurance companies and on authorities of the HANFA (Croatian financial services supervisory agency); a more detailed regulation of life insurance investment products; more detailed regulations on health insurance, etc. Besides HANFA, important institutions in the insurance and reinsurance market are the Croatian Insurance Bureau and the Croatian Actuarial Association.

Considering the open questions and issues of the insurance and reinsurance industry, it was expected that insurers would emphasize preparations for liberalizing insurance markets from self-responsibility, which started on 1st January 2008. However, most of the insurance companies have focused their considerations of the insurers' actual position on fairly deliberate criticism towards the existing regulations.

The most important regulations for the insurance and reinsurance market in Croatia are:

- The Insurance Act (Official Gazette of the Republic of Croatia, No. 151/05),

- The Act on Compulsory Insurance within the Transport Sector (Official Gazette of the Republic of Croatia, No. 151/05),

- The Law on Pension Insurance Companies and Payment of Pension Annuities based on Individual Capitalized Savings (Official Gazette of the Republic of Croatia, No. 106/99 and 63/00).

The general opinion is that existing regulations and laws do not contribute to more efficient insurance and reinsurance market development in the Republic of Croatia, but significantly interfere and hinder it. Considering the legislation and the state, most of the insurance companies harshly demand introducing changes to tax policy which would accelerate the development of the life insurance industry. Therefore, insurance companies are seriously proposing that employers should be exempted from paying taxes for the life insurance of their employees, which is the case in most countries in the European Union. The problem of faster development of voluntary health insurance could be solved in a similar way.

\section{c) Republic of Serbia}

Implementation of the process of introducing the insurance industry into the legislative framework is decisive and one of the prerequisites of the insurance markets' further growth. There is an evident need to additionally regulate this area (e.g., to place the insurance of self-reliability into a very rigid and clear regulation framework with clear and unique rules that must be observed and whose neglect should be rigorously punished; the role of agencies, representatives, technical 
inspections, etc.). When passing certain regulations, it is necessary to be well acquainted with all the particularities of the industry sector in the Republic of Serbia, and to adopt current positive practices in place in surrounding countries.

In the creation of the investment portfolios of insurance companies, there is very intense cooperation between banks and insurance companies (free assets deposition in commercial banks). Insurance companies are forced to invest their free assets through banks, since the other possibilities of investing financial assets in the Republic of Serbia are still undeveloped or they involve a large factor of uncontrolled risk (e.g. trading on the stock market where the income is very uncertain, and especially the small number of firms on the ' $A$ ' listing of the Belgrade Stock Exchange). Thus, legislation and sublegal acts which limit investments and deposits of financial assets need to recognize the environment and the possibilities of the market to absorb the needs of insurance companies for the profitable investment of their free assets, as well as the shallow offerings of securities.

The most important regulations for the insurance and reinsurance market in Serbia are:

- Insurance Law (Official Gazette of the Republic of Serbia, No. 55/04, 70/04 and 61/05),

- Property and Personal Insurance Law (FRY Official Gazette, No. 30/96, 57/98, 53/99 and 55/99 provisions on compulsory insurance and provisions on public authorizations),

- Law on Voluntary Pension Funds and Pension Schemes (Official Gazette of the Republic of Serbia, No. 85/3005),

- Law on Bankruptcy and Liquidation of Banks and Insurance Companies (Official Gazette of the Republic of Serbia, No. 61/2005).

Pursuant to the Insurance Law (Official Gazette of the RS, No. 55/2004) and the Law on Supplementing the Law on the National Bank of Serbia (Official Gazette of the RS, No. 55/2004) oversight of insurance activity has been entrusted to the NBS. Thereby the first step was taken towards introducing an integral supervision of the entire financial sector. Central bank independence and autonomy, infrastructure and staff capacity for performing supervisory tasks, as well as connections between banks and insurance companies, were the main advantages in deciding that the NBS be invested with such authority. Other institutions on the insurance and reinsurance market in Serbia are: the Association of Insurers, the Association for the Insurance Law of Serbia and the Actuarial Association of Serbia.

Within its new function the NBS will carry out supervision of insurance activity; issue licenses for performing insurance, reinsurance, intermediation and agency operations as well as those directly associated with insurance activity; give approval for legally required enactments and actions; adopt regulations prescribed by law; process statistical and other data, and consider complaints filed by the insured and other insurance beneficiaries.

Transparent procedures of decision making and imposing corrective measures, as well as orientation towards the future with a view to continued implementation of financial sector reforms, are the basic principles the NBS will follow in exercising supervision in the insurance domain.

Insurance supervision was entrusted to the NBS for several reasons:

- relations between banks and insurance companies,

- need for consolidated supervision,

- pace of implementation of legal regulations,

- institutional framework.

The passing of the new Law on Insurance was a necessary condition for the restructuring of the sector, but it alone is not sufficient. The Law passed on May 21, 2004, came into effect eight days later and the public dispute lasted for two years. It complies with EU directives and international standards.

2) Global trends in insurance and reinsurance markets have undeniable influence on the further growth and development of local markets, as well as on the adequate market positioning of both global and local insurance and reinsurance companies. Namely, one of the main effects of globalization on these markets is accelerated liberalization, accompanied by a huge concentration of insurance and reinsurance companies on the local level. Institutional capacities, as well as the adaptability of existing participants on the insurance and reinsurance markets in the countries of the region are of key importance for adjusting to turbulent changes in this commercial sector. They especially influence the ability to respond to newly created business challenges and possibilities. 


\section{a) Republic of Slovenia}

The distinctive changes to the insurance and reinsurance market of the Republic of Slovenia are obvious, especially after its admission into the European Union. Namely, there was a need to create new conditions on this market for the operation of insurance and reinsurance companies. The key challenge is the further liberalization of the insurance and reinsurance market, as well as its implications on further growth and development. Foreign insurance and reinsurance companies can directly operate in the Republic of Slovenia based on the FOS (Freedom of Service System). The global trends of creating unified insurance and reinsurance markets increased competition on this market, with consequences both on the micro and macro levels. However, significant business possibilities for Slovenian insurance and reinsurance companies on the leading markets of EU members have been also created.

\section{b) The Republic of Croatia}

The liberalization of the insurance and reinsurance market in the Republic of Croatia has increased the dominance of foreign insurance and reinsurance companies in terms of premiums, as well as in the number of active insurance and reinsurance companies. Also, the main characteristic and challenge on this market is the high concentration of the leading insurance companies, which has implications on the development of business operations and to some extent the possibility of market de-monopolization. The Republic of Croatia has addressed the challenge by strengthening the role of the 'Croatian Financial Services Supervisory Agency' (HANFA). The general belief is that HANFA largely contributed to positive developments in the insurance and reinsurance market of Croatia. The role of this agency is particularly notable in market liberalization. The necessity of education and constant perfection of employees in order to achieve competitive advantages among insurance and reinsurance companies in globalized operations is evident. Therefore, an Insurance Institute has been established in the Republic of Croatia, which is the first institute of this type with the primary task of permanently educating, training and informing employees in the area of insurance. The institutional bases are thereby strengthened in order to adequately respond to challenges in the process of accommodation to global trends.

\section{c) The Republic of Serbia}

The characteristics of national insurance and reinsurance markets largely determine the possibilities to act appropriately to newly created conditions on the global market. The main challenges on these markets are liberalization and concentration, just as on the market of the Republic of Croatia. Also, it is necessary to define general and specific goals that need to be effectively and efficiently implemented through a clearly defined strategy of insurance and reinsurance in the Republic of Serbia. This is the only way to increase competitiveness, i.e. the ability of insurance and reinsurance companies in the Republic of Serbia to adjust to changes largely induced by the intense process of globalization. Also, this would increase the level of the adaptability of insurance companies, especially bearing in mind the particularities of these markets in the Republic of Serbia.

The developmental strategy of the insurance and reinsurance markets in the Republic of Serbia should determine the future model of the insurance and reinsurance market. The strategy needs to be formulated adequately, with special focus on the factors of dynamic surroundings. Also, the influence of globalization on these markets needs to be considered with all its positive and negative side effects. Therefore, when defining the future model of the insurance and reinsurance market it is necessary to bear in mind the following: problems of insurance privatization; determination of optimum ratio of domestic and foreign capital; existing and new products (domestic, foreign insurers) and domestic insurers on the foreign market.

The goals that could be accomplished by the implemented insurance and reinsurance strategy are the following:

- Construction of an efficient insurance and reinsurance protection system;

- Transition from extensive insurance and reinsurance market development to intensive development;

- Creation of competitive environment;

- Application of EU and international standards (accounting, actuary, etc.);

- Increasing insurance and reinsurance service quality;

- Introduction of new insurance and reinsurance products;

- Strengthening public confidence in the institution of insurance; 
- Raising the level of public insurance and reinsurance knowledge and culture;

- Advancement of survey methodology on the insurance and reinsurance market;

- Integration of insurance and reinsurance market of Serbia into the regional market and the EU market;

According to the abovementioned goals that need to be accomplished in order to create an efficient and effective competitive insurance and reinsurance market, both on local and global levels in the phases of implementing insurance and reinsurance strategies in the Republic of Serbia, it is necessary to include the following:

1) Analysis and evaluation of the insurance and reinsurance market;

2) Choice of the insurance and reinsurance markets' future model, elaboration of key parameters;

3) Elaboration and introduction of EU standards (Basel II) and international standards (application of STO standards, international accounting and actuary standards);

4) Developmental stimulation of life and voluntary health and pension insurance;

5) Integration of insurance and reinsurance market of Serbia with that of the EU;

While considering the choice of future model of the insurance and reinsurance market, we should keep in mind the following:

1) Market liberalization - full or precisely determined?

2) Privatization of insurance - pro et contra

3) Ratio of foreign and domestic capital

4) Types of insurance (foreign, domestic clients)

5) Foreign investments in the insurance and reinsurance market of the Republic of Serbia

3) According to the results obtained in this research, it can be concluded that the insurance markets in the Republic of Slovenia, the Republic of Croatia and the Republic of Serbia are mutually correlated, although the markets are at different stages of development. The markets in focus show steady trends of growth and development, especially while adjusting to new conditions due to the process of globalization and concentration. It is also important to understand the causal connection, i.e. the influence of these markets on global trends in this area. The insurance and reinsurance market of the Republic of Slovenia especially is highly specific, since it is largely part of the integration processes in the EU. Global macroeconomic environment in 2007 was specific and representative because of substantial economic growth in most countries of Eastern Europe, as well as controlled inflation. In 2007 global growth of GDP was substantial. Namely, the insurance and reinsurance market in the Republic of Serbia was stabilized through the creation of an adequate environment, which opened the way for the entry of serious strategic partners of insurance and reinsurance companies with majority foreign ownership. However, despite the sustainable nondevelopment of the insurance and reinsurance market of the Republic of Serbia in comparison with the markets of the countries investigated here, there is considerable potential for the rapid growth and development of these markets (Table 3).

The further advancement in business operations in the Republic of Serbia largely depends on integrative processes as well (admission into the EU). Regional cooperation is a fundamental aspect of Serbia's EU integration (Ristic 2009, p. 117). Therefore, the ability to adapt national legislation in this area is a relevant factor of the growth and development of the insurance and reinsurance market. Also, the comparative advantages of the insurance and reinsurance market in the Republic of Serbia are beyond doubt, especially bearing in mind the existing system of prerequisites for its further growth and development (government regulations, etc.). However, the only way to create stable conditions for the efficient and effective operation of insurance and reinsurance companies is to understand national markets, both in the form of their regional connection and individually, and recognize their particularities.

\section{Conclusion}

The growing presence of business globalization and its associated consolidation, deregulation, new distribution channels and new customer demands, are only a few of the key forces leading to the reorganization of business dealings of present day insurance and reinsurance companies with regard to capital allocation, product development, processing of damage claims, and enhancement of business efficiency. The truly global approach to insurance and reinsurance business has become more and more important.

Bearing the above mentioned in mind, the emerging markets, including insurance and reinsurance markets of 
selected former Yugoslav countries, which are characterized by the continuous process of integration into the global economy, increasingly attract the attention of global insurers. According to current trends in migration from rural to urban areas, business development and concentration of material goods, we could expect growing human victims and material damage as a general trend in the future period, which will present insurance and reinsurance companies with the problem of finding adequate solutions to minimize the impact, with global risk diversification the most efficient one. Across the industry, however, insurance and reinsurance companies face a range of common challenges. They need to develop innovative bundles of products and services to drive top-line growth. They must pay increasing attention to the distribution network, taking into consideration agent relationships, direct selling, and the evolving opportunities that continue to be presented by the Internet. Also, they must keep up with increasing regulatory scrutiny around security and capital requirements, as well as escalating attention to fraud, money laundering, and other wrongdoing if they are to avoid the financial and reputation risk of noncompliance. The results of the first phase of investigation have indicated the correlation, i.e. differences and similarities between the insurance and reinsurance markets of Slovenia, Croatia and Serbia, especially in comparison to the EU 15 countries' insurance and reinsurance market data. These results emphasize the fact that the markets observed are at different stages of development. The insurance and reinsurance market of Slovenia is the most developed, although there is a significant possibility for improvement and synchronization. Furthermore, the insurance and reinsurance markets of Croatia and Serbia have a sound basis for advancement with progress in EU integration processes.

Based on the results of the second phase of investigation, it could be concluded that among the routes and trends of globalization as a process itself, and current changes in the selected national insurance and reinsurance markets of Eastern Europe, there is significant interdependence among the observed samples of the three countries reflected through the dynamism of changes in these markets as a function of their adjustment to the requirements of the global environment. Thus, the national insurance and reinsurance markets of Eastern Europe are susceptible to influences and trends of globalization in the sense of their enlargement, business specialization and gradual changes in the structure of the insurance businesses.

According to the results obtained, the research confirmed the basic hypothesis, i.e. the relationship between globalization processes and the insurance and reinsurance markets of Eastern Europe is significant and mutually dependent, and suggests future changes and trends. The significance of that relationship is also confirmed by the scope and scale of the crisis which affected insurance and reinsurance markets as well, especially considering that the effects of the crisis rapidly moved from North America across the globe. In that sense, the basic problems that occurred during this research were how to diminish the influence of the growing recession, bearing in mind that concrete investigation was conducted as a function of obtaining specific data and practical profound knowledge about the reflexive relationship between trends of globalization and the insurance and reinsurance markets of Eastern Europe. Consequently, according to the results obtained in this research, the focus of future research in this area should be on testing this reflexive relationship in global recessive business conditions. Global recessive business conditions and their impact on the insurance and reinsurance markets of Eastern Europe should be also considered. $[$.

\section{References}

Association of Serbian Insurers. 2009. Rezultati poslovanja društava za osiguranje u Srbiji 2006-2008. (translation: Results of Insurance Companies Business in Republic of Serbia 2006-2008)

Croatian Financial Services Supervisory Agency (HANFA). 2008. Annual report

Cummins, J.D. and Danzon, P.M. 1997. "Price, Financial Quality, and Capital Flows in Insurance Markets". Journal of Financial Intermediation 6 (January): 3-38.

Cummins, J.D. and Weiss, W.A. 2000. "The global market for reinsurance: Consolidation, capacity, and efficiency". Brookings-Wharton Papers on Financial Services, Washington, D.C.

Dunning, J.H. 1979. "Explaining changing patterns of international production: In defence of the eclectic theory". Oxford Bulletin of Economics and Statistics, November: $34-48$

Dunning, J.H. 1988. "The Eclectic Paradigm of International Production: A Restatement and Some Possible Extensions". Journal of International Business Studies

Dunning, J.H. 1995. "Reappraising the Eclectic Paradigm in an Age of Alliance Capitalism", Journal of International Business Studies: 461-491

Dunning, J.H. 2000. The Eclectic Paradigm of International Production: A Personal Perspective, The Nature of the Transnational Firm

Ghosh, D.K. and Ariff, M. 2004. Regional Financial Markets: Issues and Policies. Greenwood Publishing Group, Westport, CT 
Hamilton, I.F.E., Pichler-Milanović, N. and Andrews, K.D. 2005. Transformation of Cities in Central and Eastern Europe: Towards Globalization. United Nations University Press, Tokyo, Japan

Insurance Agency of B\&H. 2008. Statistics of Insurance Market in Bosnia and Herzegovina

Insurance Law (Official Gazette of the Republic of Serbia, No. 55/04, 70/04 and 61/05)

Insurance Supervision Agency (ISA). 2008. Annual report 2008

Law on Insurance (Official Gazette of the Republic of Montenegro, No $78 / 06)$

Law on Insurance Companies (RS Official Gazette, No. 17/05, 01/06, and 64/06)

Law on Insurance Companies in Private Insurance (FBIH Official Gazette, No. 24/05)

Law on Supplementing the Law on the National Bank of Serbia (Official Gazette of the RS, No. 55/04)

Liedtke, P. 2007. "What's Insurance to a Modern Economy?" Geneva Papers on Risk \& Insurance - Issues \& Practice, April, Vol. 32 Issue 2: 211221

Marovic, B. and Avdalovic, V. 2006. Osiguranje i teorija rizika. (translation: Insurance and risk theory), Centar za automatizaciju i mehatroniku, Beogradska bankarska akademija, Fakultet za bankarstvo, osiguranje i finansije, Beograd

Mirdala, R. 2008. "Decomposition of External Capital Inflows and Outflows in the Small Open Transition Economy (The Case Analysis of the Slovak Republic)". Panoeconomicus, Vol. 55 (2): 219-231

MONSTAT. 2008. Statistical office of Montenegro, Statistical Yearbook (SY MNE)

National Bank of Serbia (NBS). 2008. Insurance Sector in the Republic of Serbia - annual report

Ostojic, S. 2004. Necessity of restructuring insurance companies of Serbia. Ekonomski fakultet, Subotica, Privredna izgradnja, Vol. 47 (1-2): 77-98

Plunkett, J.W. 2006. Plunkett's Insurance Industry Almanac 2007: The Only Complete Reference to the Insurance and Risk Management Industry. Plunkett Research, Ltd, Houston, TX

Prekajac, Z. 2007. "Comparison of real development levels of countries - genesis and perspectives". Panoeconomicus, Vol. 54 (1): 87101

Ristic, I. 2009. "Serbia's EU Integration Process: The Momentum of 2008". Panoeconomicus, Vol. 56 (1): 111-125

Santomero, A.M. and Cummins, J.D. 1999. Changes in the Life Insurance Industry: Efficiency Technology and Risk Management. Springer

Slovenian Insurance Association (SIA). 2008. Statistical Insurance Bulletin

The Insurance Act (Official Gazette of the Republic of Croatia, No. 151/05)

The Insurance Act - official consolidated text (Official Gazette of the Republic of Slovenia, No. 109/06, 114/06 and 9/07) 